\title{
PENDIDIKAN GENDER SEJAK USIA DINI MELALUI HYPNOPARENTING
}

\author{
Betty Yulia Wulansari \\ Universitas Muhammadiyah Ponorogo \\ bettyyulia22@gmail.com
}

\begin{abstract}
Abstrak: Kekerasan seksual yang terjadi pada anak kian meningkat. Anak perempuan lebih rentan menjadi korban keganasan para pelaku yang tidak bermoral. Anak-anak dicabuli, dinodai dan dibunuh seakan nyawa mereka tidak berharga. Hukum perlindungan anak dari kejahatan seksual sudah diterapkan di Indonesia. Akan tetapi, masih diperlukan pencegahan yang bersumber dari dalam diri anak. Pendidikan gender menjadi salah satu upaya perlindungan anak perempuan dari kekerasan seksual. Pendidikan Gender sejak dini ini betujuan agar anak perempuan mulai bisa menjaga diri dari lawan gender mereka. Pendidikan gender dapat disampaikan orang tua kepada anak perempuanya melalui metode hynoparenting menjelang tidur malam. Metode ini memanfaatkan aspek karakteristik anak usia dini dipadu dengan pemanfaatan gelombang theta pada otak. Sugesti hypnoparenting akan bertahan di memori jangka panjang anak sehingga sesuai untuk menanamkan pendidikan gender sejak usia dini.
\end{abstract}

Kata Kunci: pendidikan gender, hypnoparenting, anak usia dini

\section{Pendahuluan}

Kekerasan terhadap anak menjadi ancaman setiap orang tua. Salah satu kekerasan terhadap anak menurut Erlinda (2014) dalam materi paparan KPAI tentang Upaya Peningkatan Anak dari Bahaya Kekerasan, Pelecehan, dan Eksploitasi adalah kekerasan seksual. Setiap tahun permasalahan ini meningkat tajam. Data KPAI pada tahun 2011-2013 kasus kekerasan seksual cenderung meningkat. Bahkan, mereka memproyeksikan pada tahun 2014 peningkatannya lebih tajam.

Pada tahun 2016 beberapa kasus kekerasan seksual menjadi trending topik. Dikutip dari Brilio.Net tanggal 16 Mei 2016 ada lima kekerasan seskual yang menjadi perhatian publik yaitu (1) pada 6 Januari balita usia 3,5 tahun menjadi korban pencabulan dan pembunuhan di Hulu Kuantan; (2) polsek Banyuasin Sumatera Selatan menangkap 5 pemerkosa gadis usia 13 tahun pada 24 Januari; (3) seorang anak SD Lampung Timur berusia 10 tahun ditemukan tewas setelah diperkosa pada 17 April di sebuah gubuk tengah ladang; (4) 9 Mei seorang balita berusia 2,5 tahun ditemukan tewas setelah diperkosa di Bogor; dan (5) seorang ayah melakukan pelecehan seksual terhadap anak perempuannya berusia 10 tahun di Pangkalpinang. Beberapa contoh kasus tersebut korbannya adalah anak perempuan, dan lebih memprihatinkan lagi beberapa diantaranya adalah balita.

Kekerasan Seksual pada Anak (2011 - 2013)

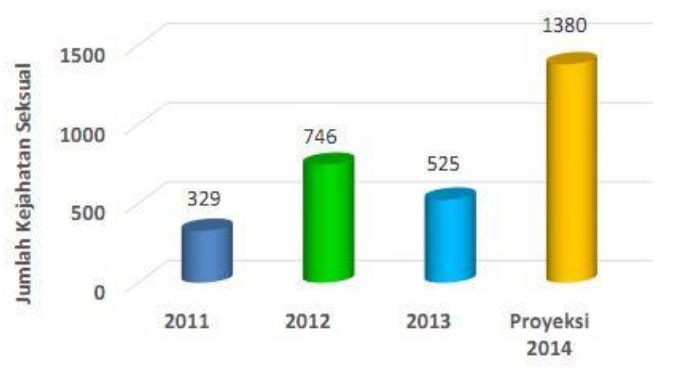

DARURAT KEKERASAN SEKSUAL TERHADAP ANAK!!

Gambar 1. Jumlah Kekerasan Seksual pada Anak data KPAI

uyjki(Erlinda, 2014) 
Upaya melindungi anak perempuan dari kekerasan seksual harus dilakukan sejak usia dini. Pendidikan gender sejak usia dini meliputi pemahaman identitas gender anak perempuan. Identitas gender yang dimaksud adalah pengenalan ciri-ciri perempuan, perbedaan dengan laki-laki, mengenal orang terdekat, dan pengenalan etika perilaku. Pendidikan ini dimaksud agar anak perempuan bisa menjaga diri dari lawan gender mereka. Pendidikan gender dapat disampaikan orang tua kepada anak perempuanya melalui pemanfaatan hynoparenting menjelang tidur malam.

\section{PEMBAHASAN}

\section{Kekerasan Seksual terhadap Perempuan}

Kekerasan terhadap perempuan adalah setiap perbuatan berdasarkan pembedaan berbasis gender yang berakibat atau mungkin berakibat kesengsaraan atau penderitaan perempuan secara fisik, seksual atau psikologis, termasuk ancaman terjadinya perbuatan tersebut, pemaksaan atau perampasan kebebasan secara sewenang-wenang, baik yang terjadi diruang publik maupun di dalam kehidupan pribadi. (Declaration on the Elimination of Violence against Women, Pasal 1: 1993)

Kekerasan seksual menurut Komnas Perempuan (2013) adalah isu penting dan rumit dari seluruh peta kekerasan terhadap perempuan karena ada dimensi yang sangat khas bagi perempuan.Persoalan ketimpangan relasi kuasa antara pelaku dan korban adalah akar kekerasan seksual terhadap perempuan. bersenjata/aparatpenduduk sipil.

Kekerasan seksual menurut Komnas Perempuan (2013) terhadap perempuan dimaknai sebagai:

1. sebuah pelanggaran hak asasi manusia yang berakar pada diskriminasi berbasis gender,
2. tindakan seksual, atau percobaan untuk mendapatkan tindakan seksual, atau ucapan yang menyasar seksual, atau tindakan untuk memperdagangkan atau tindakan yang menyasar seksualitas seseorang yang dilakukan dengan paksaan, intimidasi, ancaman, penahanan, tekanan psikologis atau penyalahgunaan kekuasaan, atau dengan mengambil kesempatan dari lingkungan yang koersif, atau atas seseorang yang tidak mampu memberikan persetujuan yang sesungguhnya

3. tindakan yang bersifat seksual itu tidak terbatas pada serangan fisik kepada tubuh seseorang dan dapat termasuk tindakantindakan yang tidak melibatkan penetrasi ataupun kontak fisik

Ruang lingkup kekerasan sesual yang sering terjadi menurut Erlinda (2014) dalam kegiatan paparan KPAI tentang Upaya Peningkatan Anak dari Bahaya Kekerasan, Pelecehan, dan Eksploitasi seperti: 1) hubungan seksual, incest, perkosaan, sodomi; 2) eksploitasi seksual dalam prostitusi atau pornografi, 3) stiulasi seksual, perabaan (molestation, fondling); memperlihatkan kemaluan kepada anak untuk tujuan kepuasan seksual; 4) memaksa anak untuk memegang kemaluan orang lain; 5) memaksa anak untuk melihat kegiatan seksual.

Menurut Komnas Perempuan (2013) ada 15 bentuk kekerasan seksual. Kelima belas jenis kekerasan seksual tersebut adalah (1) perkosaan; (2) pelecehan seksual; (3) eksploitasi seksual; (4) penyiksaan seksual; (5) perbudakan seksual; (6) intimidasi/serangan bernuansa seksual termasuk ancaman atau percobaan perkosaan; (7) prostitusi paksa; (8) pemaksaan kehamilan; (9) pemaksaan aborsi; (10) pemaksaan perkawinan; (11) perdagangan perempuan untuk tujuan seksual; (12) kontrol seksual termasuk pemaksaan busana dan kriminalisasi perempuan lewat aturan diskriminatif beralasan moralitas dan agama; (13) penghukuman tidak manusiawi 


\section{2-17| HARKAT: Media Komunikasi Islam Tentang Gender dan Anak, 12 (1), 2016}

dan bernuansa seksual; (14) praktik tradisi bernuansa seksual yang membahayakan atau mendiskriminasi perempuan, dan (15) pemaksaan kontrasepsi/sterilisasi. Dari beberapa bentuk kekerasan seksual yang paling sering terjadi adalah kasus perkosaan, dan lebih memprihatinkan pada awal tahun 2016, korban keganasan seksual adalah perempuan dibawah umur.

Pelaku tindakan perkosaan biasanya lakilaki. Perkosaan biasanya terjadi pada suatu saat dimana pelaku lebih dulu mengancam dengan memperlihatkan kekuatannya kepada anak. Jika anak diperiksa dengan segera setelah perkosaan, maka bukti fisik dapat ditemukan seperti air mani, darah, dan luka memar akibat penganiayaan. Kasus pemerkosaan dengan kekerasan pada anak memiliki beresiko menggangu ketidakstabilan emosi. Penanganan korban kekerasan seksual, perlindungan diberikan kepada anak berupa anak tidak dikembalikan di situasi terjadinya perkosaan dan anak dijauhkan dari pelaku pemerkosa.(Lukman Hakim Nainggolan, 2008: 74)

Faktor yang menyebabkan terjadinya kekerasan seksual pada anak menurut Erlinda (2014) adalah (1) rendahnya kesadaran masyarakat terhadap hak anak; (2) Pola Asuh/ pendidikan karakter dirumah; (3) kemiskinan dan lemahnya pengetahuan masyarakat; (4) belum mempunyai Sistem database tentang kekerasan terhadap anak di tingkat provinsi/ kabupaten/kota untuk menscreening potensi tindakan kekerasan di suatu wilayah; (5) penyebaran perilaku jahat antar generasi (efek dari duplikasi/ mencontoh/ meniru); (6) ketegangan sosial (pengangguran, sakit, ukuran keluarga yang besar, kehadiran seorang yg cacat mental dalam rumah, penggunaan alkohol dan obat-obatan); (7) isolasi sosial; (8) lemahnya penegakan hukum

Pola asuh atau pendidikan karakter dirumah menjadi salah satu faktor terjadinya kekerasan seksual pada anak. Menurut Edwin Ristianto (2010: 10)I slam sebagai agama rahmatan lil'alamin juga memiliki konsep maupun dasar hukum yang jelas terkait pengasuhan dan pendidikan terhadap anak. Islam memandang bahwa anak adalah anugerah sekaligus amanah dari Allah bagi kedua orangtuanya, oleh karena itu mereka

bertanggungjawab penuh atas keselamatan, kesejahteraan, serta pendidikan anak. Keselamatan anak yang menjadi tanggungjawab orangtua di sini tidak hanya sekadar keselamatan dunia melainkan juga akhirat. Seperti firman Alloh SWT pada QS At-Tahrim (66:6) yang menyebutkan bahwa orang tua diharapkan dapat memelihara diri sendiri dan keluarga baik di dunia maupun di akhirat.

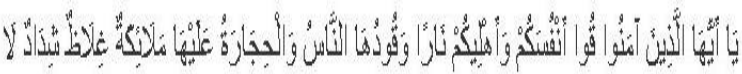

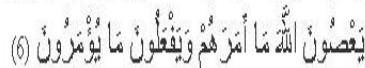

Artinya: "Hai orang-orang yang beriman, peliharalah dirimu dan keluargamu dari api neraka yang bahan bakarnya adalah manusia dan batu; penjaganya malaikat-malaikat yang kasar, yang keras, yang tidak mendurhakai Allah terhadap apa yang diperintahkan-Nya kepada mereka dan selalu mengerjakan apa yang diperintahkan."(Q.S. At-Tahrim/66:6).

Keluarga berperan penting mencegah kekerasan seksual pada anak perempuannya. Orang tua merupakan orang terdekat anak yang mampu memberikan penanaman pendidikan moral sejak usia dini. Ibu menjadi agen terpenting sebelum ayah dalam keluarga karena biasanya ia lebih dekat dengan anak perempuannya. Ibu adalah orang yang sering mengantar tidur anaknya. Aktivitas mengantar tidur anak dapat menjadi salah satu akses memberikan pendidikan gender bagi anak sejak usia dini untuk melindungi dari terjadinya kekerasan seksual. 


\section{Pendidikan Gender Anak Usia Dini}

Anak usia dini adalah anak yang berada pada masa penting dan cepat dalam kehidupan manusia. Usia dini merupakan masa awal yang penting untuk perkembangan kognitif, kesehatan, pertumbuhan emosi dan fisik anak. (Unicef, 2001: 1)

Anak usia dini menurut Muhammad Fadlillah (2014: 19) adalah anak yang berkisar antara 0-6 tahun yang memiliki pertumbuhan dan perkebangan yang luar biasa sehingga memunculka keunikan pada dirinya.

Perkembangan anak yang pesat pada masa ini membutuhkan pendampingan yang kuat untuk membentuk pribadi anak yang baik. Anak usia dini merupakan masa emas yang dapat menyerap pembelajaran lebih cepat dari usia sesudahnya. Pembekalan pendidikan gender mulai diperhitungkan untuk melindungan anak dari kejahatan seksual. Mereka perlu diberikan pemahaman mengenai gender secara kontinyu dan berkelanjutan sesuai dengan karakteristik pemahaman gender anak usia dini.

Karakteristik anak usia dini sangat unik dan sangat cepat. Burril (2009) membagi karakteristi pemahaman gender anak usia dini menjadi dua bagian.

1. Karakteristik anak lahir sampai 4 tahun

a. Anak-anak berpikir dan memahami sesuatu hal secara konkret.

b. Usia dua sampai tiga tahun anak belajar dengan imanjinasi dunianya. Mereka dapat mengindentifikasi anak perempuan dan lakilaki berdasarkan penampilan luarnya. Mereka mengenal pakaian dan mainan anak berdasarkan jenis kelamin

c. Pada usia 3-4 tahun anak telah memiliki rasa identitas gender mereka sendiri dan semakin menyadari perbedaan anatomi anak perempuan dan laki-laki. Mereka terbentuk sesuai identititas mereka berdasarkan apa yang telah mereka pelajari dari keluarga, interaksi sosial, dan informasi media.

d. Anak-anak bersifat egosentris. Mereka tidak mengenal banyak tentagng orang lain kecuali diri mereka sendiri.

e. Anak-anak memiliki rasa ingin tahu yang tinggi dab sering bertanya. Mereka memiliki rentang perhatian yang pendek. Mereka memerlukan informasi dasar dalam bentuk jawaban sedrhana. Pertanyaan serig kali datang dari apa yang anak dengar dari pengalaman hidupnya.

f. Anak-anak menggunakan cara bermain dan berpura-pura dalam mengekspresikan diri. Bermain adalah pekerjaan anak-anak.

g. Anak-anak menyerap segala sesuatu yang terjadi disekitarnya. Anak belajar sepanjang waktu melalui pengalaman dan pengamatan.

2. Karakteristik anak 5-8 tahun

a. Anak-anak masih berpikir dan memahami secara konkrit.

b. Anak masih berpusat di sekitar diri sendiri

c. Pada awal tahap ini anak-anak telah menggunakan pemikiran jenis kelamin untuk bertidak. Mereka menyadari bahwa anak perempuan berbeda dengan anak lakilaki. Hal ini terkadang membatasi ruang gerak anak-anak tetapi mereka mulai beradaptasi dengan berpikir konstruktif tentang dirinya melalui buku-buku mendongeng, dan paparan berulang-ulang dari orang disekitarnya.

d. Usia 6 tahun mereka masih berpikir untuk menjadi lawan jenis, menjadi idolanya, menjadi putri. Tapi di usia 7 tahun mereka telaha memahami stabilitas gender dan tahu bahw jenis kelamin tidak akan berubah.

e. Anak-anak mulai memiliki kemampuan yang meningkat untuk menggambarkan 


\section{4-17| HARKAT: Media Komunikasi Islam Tentang Gender dan Anak, 12 (1), 2016}

apa yang mereka pikirkan dan mereka rasakan.

f. Anak-anak mulai meimikirkan orang lain.

g. Anak-anak memiliki rasa ingin tahu yang tinggi

h. Anak-anak mulai jeli dengan lingkungan disekitar tentang apa yang mereka lihat dan mereka dengar.

i. Menjelang akhir tahap ini mereka sudah tidak memikirkan gender secara detail tetapi mereka sudah paham tentang identitas gender mereka dalam berperilaku secara spontan.

Karakteristik anak usia dini tersebut menjelaskan bahwa anak sudah mulai ingin tahu mengenai gender sejak dini. Mereka mulai melihat perbedaan lelaki dan perempuan, mulai berperilaku seperti indentitas gender mereka dengan dukungan dari interaksi sosial. Maka anak memerlukan pemahaman pendidikan gender. Salah satu waktu yang tepat adalah saat menjelang anak tidur. Saat anak mengalami transisi dari sadar menuju alam bahwah sadar terjadi pelambatan kecepatan frekuensi gelombang otak.

\section{Hypnoparenting}

Hypnoparenting adalah gabungan adari 2 kata yaiyu hipnosis, dan parenting. Menurut Ana Yuliana (2012) hipnosis adalah proses penurunan kondisi kesadaran. Kondisi ini akan terjadi dua kali dalam sehari yaitu saat akan tidur dan saat bangun tidur. Kondisi hipnosis adalah kondisi antara mata terbuka dan tidur nyenyak. Hipnosis adalah fenomena alamiah yang dialami setiap manusia. Sedangakan parenting menurut Ana Yuliana (2012) adalah segala hal yang berhubungan dengan bagaimana orang tua mendidik dan membesarkan anaknya. Penerapan Hypnoparenting adalah metode mendidik anak menggunakan pengetahuan hipnosis.
Hypnoparenting

memanfaatkan gelombang theta pada otak manusia. Menurut Ana Yuliana (2012) gelombang otak manusia memancarkan empat gelombang yaitu delta, theta, alpha, dan beta. Gelombang delta berada pada frekuensi $0,1 \mathrm{~Hz}-4 \mathrm{~Hz}$. Kondisi ini yang disebut dengan kondisi tidur nyenyak tanpa mimpi. Gelombang theta berkisar di $4 \mathrm{~Hz}-8$ Hz. Pada kondisi ini, ide kreatif dan inisiatif muncul. Informasi yang diterima otak pada saat ini akan langsung menjangkau alam bawah sadar anak dan tersimpan pada memori jangka panjang.. Gelombang selanjutnya adalah gelombang alpha. Gelombang ini berkisar antara $8 \mathrm{~Hz}$ sampai $12 \mathrm{~Hz}$. Gelombang ini terjadi pada tingkat keasadaran lebih tinggi. Pada kondisi ini, pikiran manusia hanya berpusat pada satu perhatian. Gelombang alpha dapat dilihat saat manusia berdoa secara khusuk. Kondisi kesadaran paling tinggi adalah gelombang beta. Gelombang ini terjadi pada frekuensi diatas 12 Hz. Pada kondisi ini manusia memiliki kesadaran seutuhnya. Gelombang beta memungkinkan manusia dapat beraktifitas melakukan banyak kegiatan yang mereka senangi. Dari paparan tersebut, maka gelombang theta adalah kondisi paling sugestif dan saat yang tepat untuk melakukan hypnoparenting.

Pada anak usia dini gelombang pikirannya berada pada gelombang theta-alpha. Ana Yuliana (2012) menyampaiakan bahwa para ahli teknologi pikiran menyebut fase ini sebagai fase pra-kritis. Informasi diserap dan dintegrasikan tanpa ada pertanyaan.

Pada fase pra-kritis ini apapun yang didengar, dirasakan, oleh anak-anak akan langsung masuk dan mengendap dipikiran bawah sadar. Masa ini anak sangat sugestif terhadap apapun. Pada masa ini masa anak mulai dibentuk. Orang tua dapat mengembangkan pendidikan dasar tentang sikap, konsep diri, nilai 
Tabel 1. Materi Sugesti Hypnoparenting

$\begin{array}{lll}\text { Tema Materi Sugesti Hypnoparenting } & \end{array}$

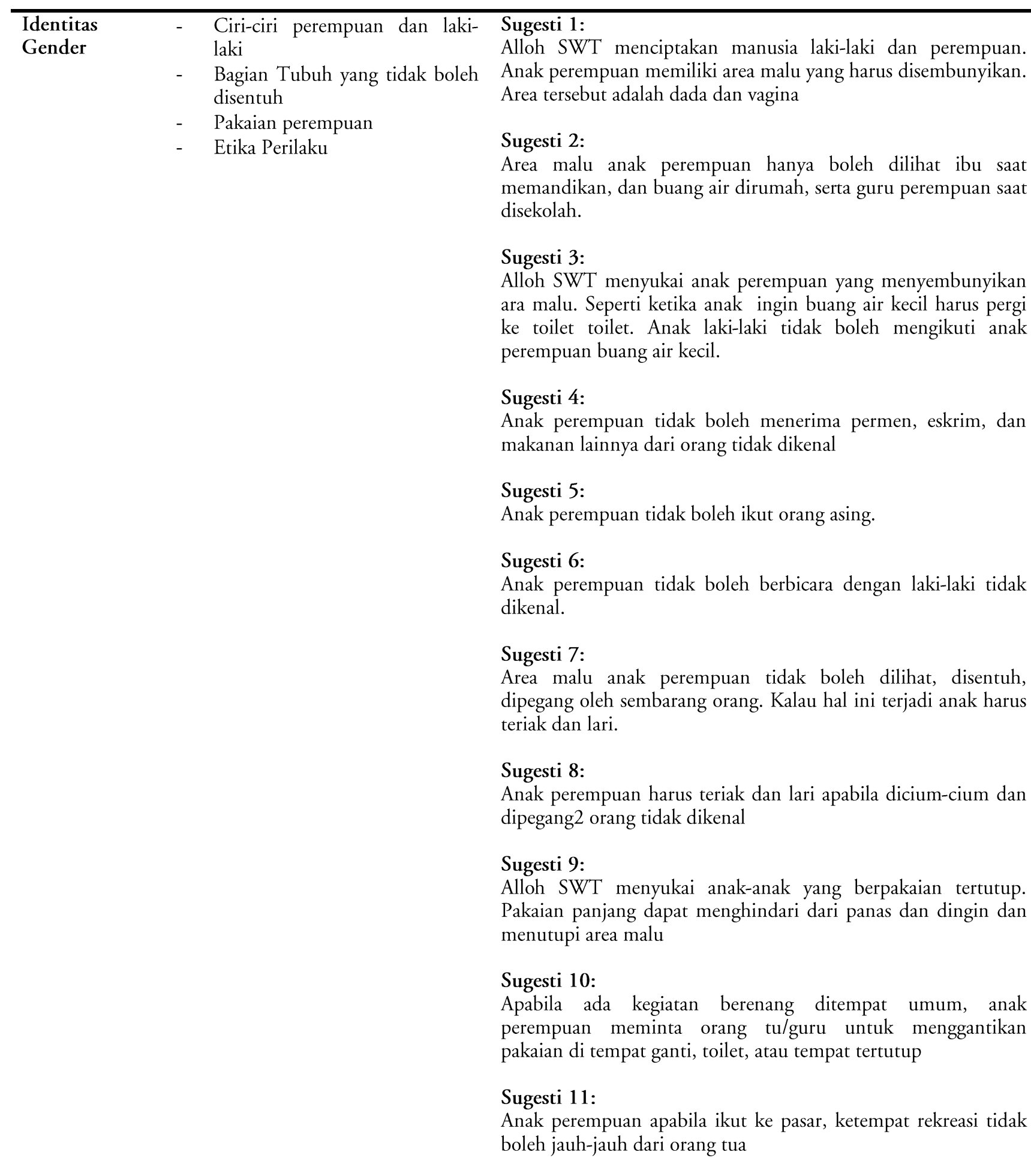

Proses hipnosis dapat dilakukan orang tua dengan pemberian sugesti saat anak menjelang tidur malam. Kegiatan dapat diawali dengan dengan mengusap kepala dan bernyanyi pelan. $\mathrm{Hal}$ ini betujuan untuk menurunkan tingkat kesadaran anak sehingga proses sugesti dengan 


\section{6-17| HARKAT: Media Komunikasi Islam Tentang Gender dan Anak, 12 (1), 2016}

kalimat singkat dapat diberikan kepada anak khususnya anak perempuan. Kalimat singkat dipilih karena fokus anak terhadap sesuatu hal relatif singkat dan retang waktu gelombang theta juga terbatas hanya saat menjelang tidur.

\section{Materi Sugesti Pendidikan Gender}

Menurut The Student Wellbeing Division (2011: 35) pendidikan gender untuk anak meliputi enam tema yaitu : mengenal saya, mengenal kamu; bertumbuh dan berubah, tubuhku, kepemilikan, sesorang yang diajak berbicara, dan dimana aku berasal. Anak usia dini mulai membandingkan diri sendiri terhadap orang lain. Ketika anak perempuan buang air kecil bersama anak laki-laki, ketika anak perempuan dan anak laki-lki mandi di lokasi yang sama. Mereka mulai bertanya perbedaan alat kelamin. Anak anak perlu memahami bagian-bagian seksual dari tubuh tubuhnya melalui komunikasi yang jelas dan secara nyata.

Penjelasan tema The Student Wellbeing Division, diambil satu tema untuk hypnoparenting anak perempuan yaitu Identitas Gender. Adapun materi sugestindan bentuk sugestinya dapat dilihat pada Tabel 1 .

\section{Prosedur Pelaksanaan Hypnoparenting}

Pelaksanaan pemberian sugesti dalam hypnoparenting mudah diterapkan olah orang tua. Adapun prosedur pelaksanaannya:

1. Sugesti dilakukan orang tua menjelang tidur malam.

2. Sebelum memberikan sugesti, orang tua dapat menurunkan tingkat kesadaran anakmelalui usapan di kepala dan dengan nyanyian lembut. Setelah itu baru memberikan sugesti bermuatan gender pada anak.

3. Sugesti bermuatan pendidikan gender, artinya sesuai dengan tema identitas gender.
4. Kalimat sugesti tidak telalu panjang, hal ini karena anak memiliki fokus yang singkat.

5. Sugesti dilakukan berulang secara berselang seling agar anak tidak merasa bosan.

\section{Kelebihan hypnoparenting}

Penerapan hypnoparenting untuk anak usia dini memanfaatkan dua aspek kondisi yang mendukung keberhasilan penanaman pemahaman gender. Aspek pertama memanfaatkan karakteristik anak usia dini yang berada pada tahap pra-kritis. Anak pada tahap ini akan menerima informasi apapun tanpa bertanya. Aspek kedua adalah pemanfaatan keadaan gelombang theta pada otak anak untuk memeberikan sugesti singkat pemahaman gender. Sugesti ini diharapkan akan bertahan di memori jangka panjang anak. Penerapan hypnoparenting mudah dilakukan oleh orang tua setiap malam.

\section{Simpulan}

Kekerasan seksual menjadi salah satu tangung jawab orang tua. Mereka memiliki andil terhadap perlindungan anak perempuan dari kekerasan seksual yang menghantui di masyarakat saat ini. Pendidikan Gender sejak dini ini betujuan agar anak perempuan mulai bisa menjaga diri dari lawan gender mereka. Salah satu cara menyampaikan pendidikan gender pada anak melalui penerapan hynoparenting.

Penerapan hypnoparenting untuk anak usia dini memanfaatkan dua aspek kondisi yang mendukung keberhasilan penanaman pemahaman gender. Aspek pertama memanfaatkan karakteristik anak usia dini yang berada pada tahap pra-kritis. Anak pada tahap ini akan menerima informasi apapun tanpa bertanya. Aspek kedua adalah pemanfaatan keadaan gelombang theta pada otak anak untuk 
gender. Sugesti ini diharapkan akan bertahan di memori jangka panjang anak. Penerapan hypnoparenting mudah dilakukan oleh orang tua setiap malam.

\section{Daftar Pustaka}

Burril, Melany. (2009). Childhood Development Characteristic \& Basic Message About Sexual Orientation and Gender Indentify. Diunnduh pada 12 Juli 2016 dari www.manyvoice.org

Erlinda. (November 2014). Upaya Peningkatan Anak dari Bahaya Kekerasan, Pelecehanan Eksploitasi. Paparan Sosialisasi KPAI di Kementrian Kominfo Diunduh tanggal 12 Juli 2016 dari https://web.kominfo.go.id/sites/default/file s/users/12/SESI\%20II\%20-

\%202.\%20paparan-kementerian-2014nov-bandung-erlinda-REV-fix.pdf

Fadlillah, Muhammad. (2014). Desain Pembelajaran PAUD. Yogyakarta:Ar-Ruzz Media

Komnas Perempuan. (2013). Kekerasan Seksual. Diunduh pada 12 Juli 2016 dari http://www.komnasperempuan.go.id/wpcontent/uploads/2013/12/KekerasanSeksual-Kenali-dan-Tangani.pdf

Nainggolan, Luqman Hakim. (Februari 2008). Bentuk-bentuk Kekerasan Seksual terhadap Anak di Bawah Umur. Jurnal Equality Universitas Sumatera Utara Vol. 13 No. 1. Diunduh pada 12 Juli 2016 dari http://repository.usu.ac.id/bitstream/123456789/18417/1/equfeb2008-13\%20\%282\%29.pdf
Ristianto, Edwin. (2010). Kekerasan terhadap Anak dalam Keluarga (Tinjauan Hukum Islam terhadap UU No. 23 Tahun 2002). Skripsi. Tidak diterbitkan. Yogyakarta: UIN Sunan Kalijaga. Diunduh tanggal 12 Juli 2016 dari http://digilib.uinsuka.ac.id/5633/1/BAB\%20I,\%20V,\%20 DAFTAR\%20PUSTAKA.pdf

Undang-undang No. 23 Tahun 2004 tentang Penghapusan Kekerasan Dalam Rumah Tangga

Unicef. (2001). Early Childhood Development: The Key to A Full and Productive Life. Diunduh pada 12 Juli 2016 dari www.unicef.org/dprk/ecd

Wirawan, Sarlito, Laki-laki Memang Terlambat Dewasa, Harian Seputar Indonesia (Sindo), Kamis 13 Desember 2007.

Yuliana, Ana. (2012). Penerapan Hypnoparenting sebagai Salah Satu Metode Mendidik Anak. Arsip PLS UM untuk imadiklus.com. Diunduh pada $12 \mathrm{Juli}$ 2016 dari imadiklus.googlecode.com/files

Zahrah, Muhammad Abû, Al-Ahwâl alSyakhshiyyah, (Kairo: Dâr al-Fikr al'Arabî, t.th.).

Zamakhsyarî, Abû al-Qâsim Jâr Allah Mahmûd ibn Umar, Al-Kasysyâf 'an Haqâ̂iq alTanzîl wa 'Uyûn al-Aqâwîl fî Wujûh alTa’wîl, Jilid I (Beirut: Dâr al 